\title{
SPATIAL CHANGES OF RIVER FORMATIONS ON A PARTIALLY REGULATED RIVER
}

\author{
M. Teresa Ferreira * and J. C. Figueiredo** \\ * Departamento de Engenharia Florestal, Instituto Superior de Agronomia, Tapada da Ajuda, 1399 Lisboa, PORTUGAL \\ **Instituto da Conservaçao da Natureza, Rua Filipe Folque 46-1²,1000 Lisboa. PORTUGAL
}

Keywords: regulated rivers, vegetation changes.

\section{RESUMEN}

VARIACIONES ESPACIALES DE FORMACIONES LÓTICAS EN UN RIO PARCIALMENTE REGULADO.

El tramo final del rio de $21,5 \mathrm{Km}$. que discurre por un regadio fué estudiado y se mapearon 5 formaciones de habitat, medidas conjuntamente con las caracteristicas de la vegetación asociada. Los primeros 7,5 Km. están canalizados en línea recta por el lado externo de las orillas; los ultimos $2,5 \mathrm{Km}$. tienen forma trapezoidal y fueron dragados. Entre éstos el rio discurre libremente a través de la llanura de inundación. La cobertura riparia fué mas elevada en el sector rectilineo e inversamente correlacionada con la arena humeda y superficies marginales dominadas por helófitos e hidrófitos. Las áreas de terreno seco. colonizadas por plantas terrestres, están asociadas con las zonas de ensanche y muestran un valor mas elevado en el sector no regulado. La cobertura de hidrofitos y particularmente de Myriophyllum aquaticum, una planta acuatica exótica, se incrementa aguas abajo con la intensificación de los cultivos y es máxima en la parte estudiada. Los resultados son discutidos en términos de efectos de rios regulados.

\section{INTRODUCTION}

The intervention of man upon river systems took place almost everywhere in Europe (BROOKES, 1988). However, only during the last two decades the consequences of alterations in river habitats and their biological assemblages have received more attention from freshwater ecologists, and in some cases resulted in mitigation or recovery measures (GARDINER, 1991). In Portugal, the straightening, resectioning and dredging of river beds are associated with agriculture and fisheries activities and occur specially in central and southern littoral areas (FERREIRA \& FIGUEIREDO, 1990a and b). No damage assessment of the various river regulation activities currently used was ever done. In this work, the spatial changes of macrophyte assemblages on a river stretch with three different types and levels of intervention is studied.

\section{STUDY AREA}

The river Sorraia, the largest southern tributary of the Tejo system, is the main axis of a fertile alluvial plain dominated by rice fields and irrigation crops. Within the area of the basin, villages are small and scattered, existing only a few industries. In Portugal, approximately 50.000 ha of irrigation crops are included within Irrigation Areas (IA) and the Sorraia Valley is one of the three largest (around 16.400 ha of irrigation). The river engineering that created these IA dates from the period 1935-65 and reflects an epoch of ambitious schemes in river manipulation common to many European countries. All Portuguese IA are based upon one or more upstream multipurpose reservoirs (hydroelectricity, flood control and irrigation); the hypolimnetic water is conducted in concrete canals by pumping or gravity, and distributed to the farmers downstream in proportion to their annual crop area and crop needs; the outflows are then discharged to rivulets and/or directly into the main river.

Within most IA, the main river is subjected to interventions of resectioning, straightening and embanking, in order to improve flood control and increase the crop areas around. No environmental impact assessment or mitigation measures were taken in these river manipulations, which proceed eventually nowadays, as on the Mondego Valley up to 1986. Not surprisingly, most IA presently deal with management problems such as a general impoverishment of fish assemblages, the proliferation of exotic aquatic weeds and certain riparian trees, and also of ani- 
mals like the american crayfish Procambarus clarkii. The lotic corridors are highly subjected to human pressure, namely water pumping, irrigation discharges, riparian cutting fishing and recreation.

\section{METHODS}

A river stretch between Couço and Coruche (Figure 1) was completely surveyed during July-August 1989 and divided into sections of $0.5 \mathrm{~km}$, with a total of 43 sections. This particular strecht was chosen because it includes three different and successive areas and levels of manipulation: $7.5 \mathrm{~km}$ of straightening of the outer banks, reinforced by a series of boulder gabion groynes built normal to the bank, and dating from 1965; $11.5 \mathrm{~km}$ of more or less 'free' (unregulated) river channel and corridor; and 2.5 $\mathrm{km}$ of river manipulation including resectionning, deepe-

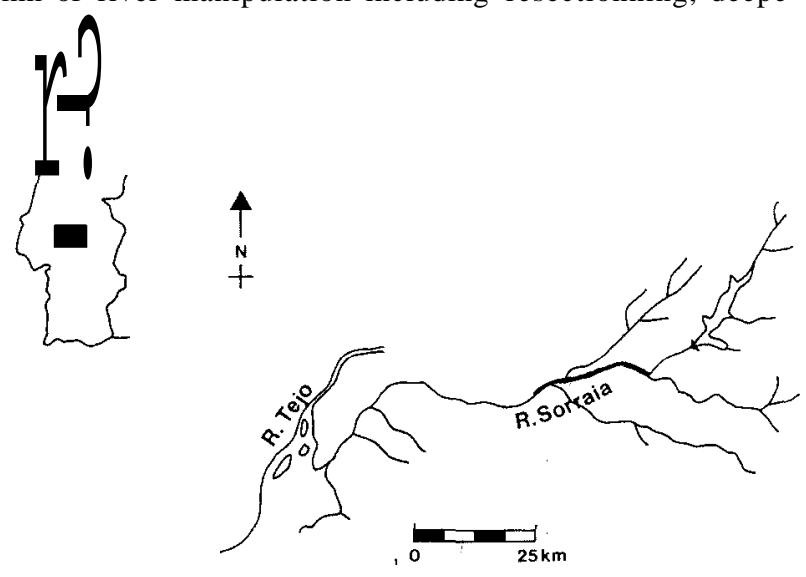

FIGURE 1. River Sorraia, showing in bold the river stretch studied. Small figure shows the location of the basin in Portugal.

FIGURA 1.- Encuadramiento de la cuenca en Portugal. Rio Sorraia, donde se señala el tramo estudiado.

ning, dredging and plant clearing on an annual basis, related to angling activities.

Five river formations, corresponding to particular plant habitats and plant assemblages, were visually identified inside each section considered and their areas mapped and measured with a planimeter (in $\mathrm{m}^{2}$ ): riparian belt, dry sand deposits, wet and waterlogged sand deposits, water margins and aquatic (submerged) surfaces. Plant assemblages of each river formation were characterised. In each section, the total area (in $\mathrm{m}^{2}$ ), the aquatic (submerged) area (in $\mathrm{m}^{2}$ ) and the section width gap (difference between maximum and minimum width, $\mathrm{m}$ ) were also determined. The end of the riparian belt and the beginning of the surrounding crops were considered the outer limits of the river. Pearson's correlations were determined for these measurements, as well as their levels of significance at $\mathrm{p}>0,05$.

\section{RESULTS}

\section{Characterisation of river formations}

The visual observation of plant assemblages and river habitats allowed the establishment of five river formations producing different vegetation types. Upper and inner banks are generally occupied by dense stands of riparian trees, dominated by Salix alba ssp. vitelina and S. salvifolia ssp. salvifolia that eventually reach an invasive status and are subject to cuttings by the farmers (FERREIRA \& MOREIRA, 1989). Under the canopy, some shade terrestrials like Arum italicum, Geranium lucidum and Lamium amplexicaule occur.

The river bed is dominated by sand materials forming a mosaic of sand bars with different shapes and disposition, especially channel side bars, point bars and mid-channel bars. Sand accumulations high above the water level result in permanently dry surfaces occupied by heliophilous and psammophilous terrestrials like Spergula arvensis, Avena barbata, Aster squamatus, Conyza alhida, Chenopodium album and Hordeum murinum. Sand accumulations near the water tend to be flat and waterlogged, dominated by small herbaceous like Digitaria sanguinalis, Echinochloa crus-galli, Cyperus difformis, Polygonum aviculare, Lindernia dubia, Veronica anagalloides and Paspalum paspalodes.

In close association with the aquatic environment, the margins are colonised by tall and herbaceous stands of Sparganium erectum, Typha latijolia, Cyperus eragrostis, C. longus, Polygonum hydropiper, P. lapathifolium, Scirpus lacustris, Polypogon monspeliensis and Lysimachia vulgaris. Hydrophyte assemblages are dominated by $M y$ riophyllum aquaticum in most sites, however, frequent stands of Ceratophyllum demersum, Potamogeton fluitans and $P$. crispus also occur.

Vegetation cover of these river formations is variable. Riparian areas and marginal habitats are fully occupied by plants. Dry and wet sands, as well as aquatic habitats, present smaller covers, roughly between 50 and $75 \%$, and increasing during growth season. Results were obtained during August 1989. 


\section{Spatial changes of river formations}

The evolution of the total area of the sections and of the aquatic (submerged) area are shown on Figure 2. The total area and the section width gap show small variations in the straightened part of the river stretch and large variations in the unregulated part. A certain amount of these variations results from the inflows of two tributaries, rivers Divor and Erra (Figure 1). The last part of the river stretch is narrower and shows a small width gap and a reduced total area, at the expenses of the sand deposits and

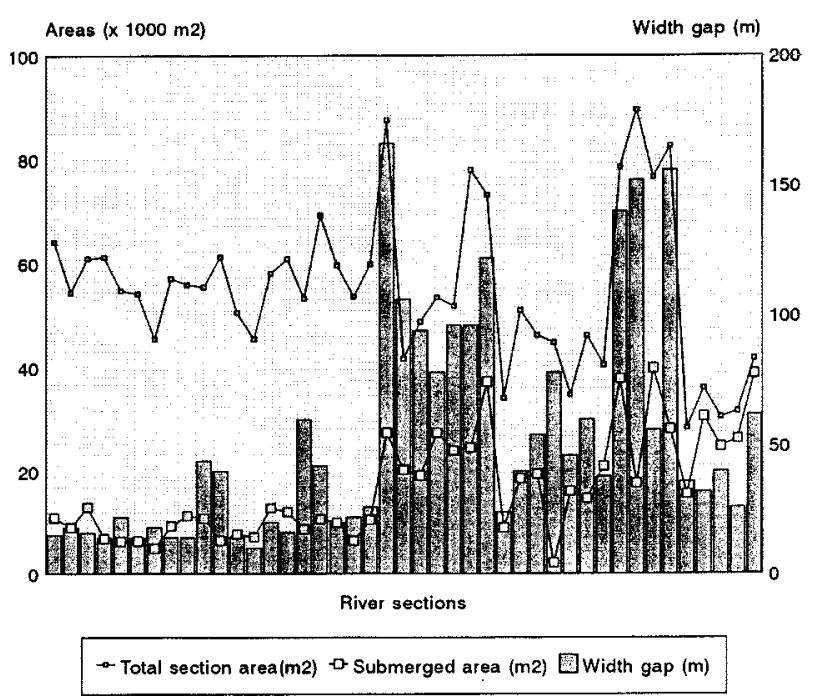

FIGURE 2. Spatial evolution of the total area $\left(\mathrm{m}^{2}\right)$, submerged area $\left(\mathrm{m}^{2}\right)$ and width gap $(\mathrm{m})$ in each section of the river stretch studied.

FIGURA 2.- Evolución espacial del área total $\left(\mathrm{m}^{2}\right)$, área sumergida $\left(\mathrm{m}^{2}\right)$, y amplitud del lecho $(\mathrm{m})$ en cada sección del tramo del río estudiado.

inner bank, which are dredged and deepened each year. The aquatic (submerged) area shows a similar pattern in the fist two parts of the river but proportionally increases in the last part, where all river bed is flooded to increase the potential fish biomass.

The mosaism of the sand deposits results in different dimensions, shapes and disposition of the bars, and the area of the water surfaces are quite variable. No significant correlation was found between the total area of the sections and the aquatic (submerged) area, not even just for the sections of the unregulated part.

Figure 3 shows the evolution of the river formations directly associated with the water environment: i) marginal helophytes; and ii) hydrophytes. A third area was also determined, the cover of parrotfeather ( $M$. aquaticum).

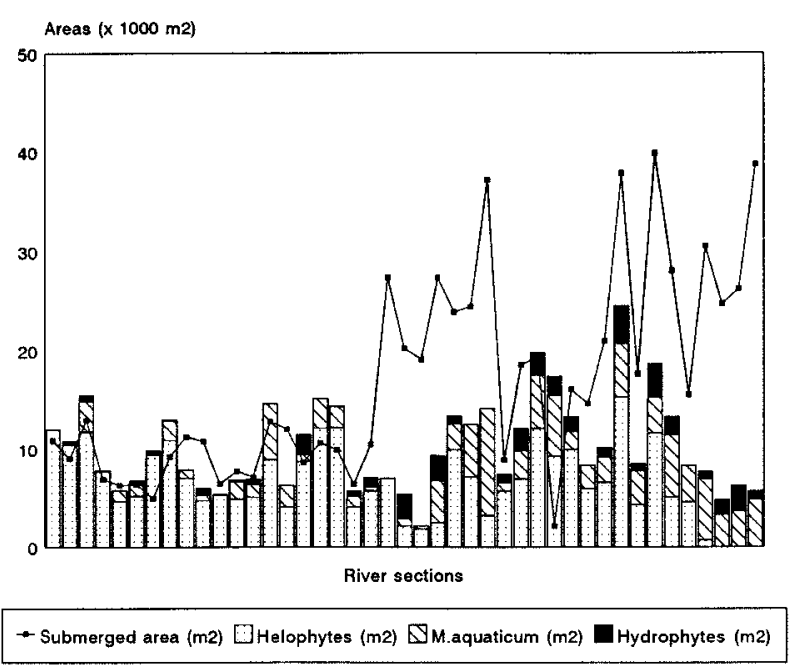

FIGURE 3. Spatial evolution of the areas of marginal helophytes $\left(\mathrm{m}^{2}\right)$, indigenous hydrophytes $\left(\mathrm{m}^{2}\right)$ and parrotfeather $\left(\mathrm{m}^{2}\right)$ in each section of the river stretch studied. Also shown is the submerged area of each section $\left(\mathrm{m}^{2}\right)$.

FIGURA 3.- Evolución espacial de las áreas de helófitos marginales $\left(\mathrm{m}^{2}\right)$, hiđrófitos autóctonos $\left(\mathrm{m}^{2}\right)$ y exóticos $\left(\mathrm{m}^{2}\right)$ en cada sección del tramo del río estudiado. Se señala el área sumergida de cada sección.

The area of this exotic Haloragaceae was given a special attention because of its weed character and large development in all central and southern Portuguese river lowlands.

Helophyte areas show an irregular evolution, probably dependent from the mosaism of the sand deposits and the meandering of the river channel, that eventually create soft sloped margins with local depositions of fine particulate materials, favouring helophyte establishment. Helophytes disappeared from the deepened and dredged part of the river, where a water depth of 2-3 m is kept constant in all river bed for angling purposes. On the contrary, this is a situation that encourages the establishment of large hydrophyte assemblages. The submerged area have a positive significant correlation with the cover of the indigenous hydrophytes and also the cover of $M$. aquaticum. Very large submerged areas, which are shallow and slowflowing water surfaces, occur only in some sections of the unregulated part (sections 21 to 28 ) and in the sections used for angling (sections 40 to 43 ).

However, non-parrotfeather hydrophytes and $M$. aquaticum show somewhat different evolutions. Both hydrophytes and parrotfeather have small cover in the first and straightened part of the river. Downstream, M. aquaticum shows a constant increase (reaching $10.960 \mathrm{~m}^{2}$ in section 27 ), while hydrophytes, though also generally increasing, 
have almost always smaller areas and show large variations, from absent to $3.480 \mathrm{~m}^{2}$ in river section 35 , corresponding to a large and shallow water surface associated with an increase of the total area of the section. The indigenous hydrophyte area exceeds M. aquaticum only in two sections of the unregulated part, sections 16 and 22 .

Figure 4 shows the evolution of the transitional aquatic/terrestrial formations: i) wet and waterlogged sand accumulations, that is, shallow deposits near the river margin, periodically submerged; ii) large and dry sand deposits; and iii) inner bank, generally occupied by riparian trees and under-canopy hygrophytes and terrestrials. Riparian trees totally dominate the site formations in the straightened part of the river but have less important areas in the unregulated part. An exception is site 31 where the river is very narrow and deep, running through dense riparian woods of Salix salvifolia ssp. salvijolia and Salix alba ssp. vitelina Riparian areas show a significant inverse correlation with the submerged area and the cover of hydrophytes. A highly managed area of riparian tree (mostly Populus nigra and Fraxinus angustifolia) is kept along the last part of the river.

Dry sand deposits have constant and small areas along the river, but show an exceptional increase after the con-

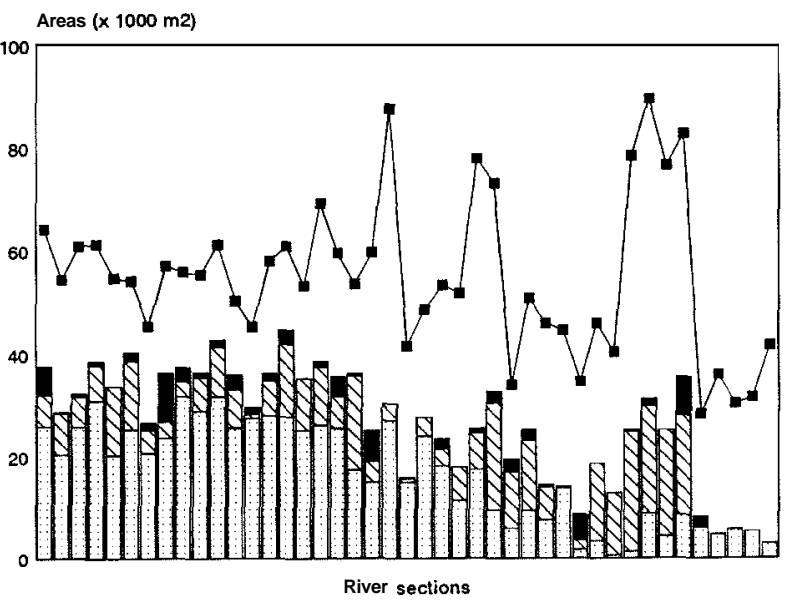

- Total area (m2) $\square$ Riparian trees (m2) $\square$ Dry sands (m2) $\square$ Wet sands (m2)

FIGURE 4. Spatial evolution of the areas of riparian trees $\left(\mathrm{m}^{\mathrm{Z}}\right)$, dry sand deposits $\left(\mathrm{m}^{2}\right)$ and wet and waterlogged sand deposits $\left(\mathrm{m}^{2}\right)$ in each section of the river stretch studied. Also shown is the total area of each section $\left(\mathrm{m}^{\mathrm{Z}}\right)$.

FIGURA 4.- Evolución espacial de las áreas de vegetación de ribera $\left(\mathrm{m}^{\mathrm{Z}}\right)$, depósitos de arena seca $\left(\mathrm{m}^{\mathrm{z}}\right)$ y humeda $\left(\mathrm{m}^{\mathrm{Z}}\right)$ en cada sección del tramo del río estudiado. Se señala el área total de cada sección $\left(\mathrm{m}^{\mathrm{Z}}\right)$. fluence of rivers Erra and Divor along with an increase in the total area of the sections. The rivers Erra and Divor are known to have drainage basins with an important ongoing erosion process (CARVALHO \& MIRANDA, 1982), and sand extraction activities are frequent in these sections. Wet and waterlogged sand deposits present variable and generally small areas. These are ephemeral formations dependent from the local pattern of river sinuosities, that can eventually evolve to more or less permanent helophyte stands or be carried downstream in winter flood conditions.

\section{DISCUSSION}

The rectangular cross-shape section of the last part of the studied stretch results in the disappearance of most river formations and habitats and in a large decrease in plant richness, but also in a highly favourable submerged environment to hydrophyte assemblages. However, this type of intervention is performed only in small river stretches and social benefits through angling can be considered high. Clearly there has to be some type of compromise in conflicts of water use of this type.

Hydrophytes are well established in these sections in spite of the yearly bed manipulation. The recovery of river hydrophytes following channelization and dredging can vary greatly, depending on the type of channel and the extent and periodicity of the works (BROOKES, 1988). However, the development of hydrophytes seems to occur whenever silt accumulates (HASLAM, 1978) and, in fact, a small impoundment controled by gates limits this river zone, acting as a silt trap between May and September each year. Dredging is conducted in April near the margins and a certain amount of plant rhizomes remain in the channel bed, allowing an easy regrowth; a similar situation is mentioned by BROOKES (1987b) in Wallop Brook, Hampshire (U.K.).

The downstream increase of parrotfeather density and cover occurs in the studied stretch and is a general feature in the Sorraia basin, where this exotic plant presents a significant positive correlation with the enlargement of crop areas (FERREIRA, 1992). The Sorraia basin presents in general high mineralised and nutrient-rich waters, but still some human induced disturbance factor is probably involved is this downstream dominance.

The unregulated part of the studied river stretch is characterised by an irregular succession of dominance of the river formations, within and between river sections. Parti- 
cular habitats are fayour or disappear in one or a few sections according to local river features such as channel enlargement, slope increases or local sand accumulations. Flow is unsteady and non-uniform and frequently there are several streamlines. Some morphological diversity is unique to these sections with the occurrence of a few gravel riffles, deep pools or diamond bars. Also, the frequency of certain bird species, fish assemblages or abundance of otter tracks can also be related to the dominance of particular habitats (FERREIRA \& FIGUEIREDO, 1990a and b).

The trapezoidal cross-shape sections of the first (straightened) part of the river stretch studied favour the occupation of the upper and inner bank with riparian trees (essentially willows), that can cover the river bed surface up to the water margin and need periodic cuttings. Other river formations considered (dry and wet sands and marginal helophytes) present small and uniform areas along the sections. This group of sections also presents a small total cover of hydrophytes and Myriophyllum aquaticum, associated with an also small submerged (available) area, in a single streamline, relatively constant in width, favouring plants with marginal anchoring like parrotfeather. However, river formations and associated vegetation found are identical to those existing in the unregulated sections.

The straightening and consolidation of the outer banks, instead of the summer river channel as often is the engineering practise, allowed a sufficiently wider streamway for the development of different river formations, therefore minimising the effect of manipulation. BROOKES (1988) refers to this scheme as the 'corridor concept', that is, the confinement of the meander belt to a fixed position on a floodplain to preserve the instream habitats. Some successful experiences in river recuperation through this concept already exist in Bavaria, West Germany (BINDER et $a l, 1983$ ) and Denmark (BROOKES, 1987a). Whenever straightening must take place, engineers should follow the option considered in this study.

\section{REFERENCES}

BINDER, W., JURGING, P. \& J. KARL. 1983. Natural river engineering- characteristics and limitations. Garten und Landschaft, 2: 91-94
BROOKES, A., 1987a. The distribution and management of channelized streams in Denmark. Regulated Rivers, 1: 3- 16

BROOKES, A., 1987b. Recovery and adjustment of aquatic vegetation within channelization works in England and Wales. Journal of Environmental Management, 24: 365-382

BROOKES, A., 1988. Channelized Rivers, Perspectives for Environmental Management. John Wiley \& Sons. Chichester.

CARVALHO, J.D. \& J.C. MIRANDA, 1982. Sistematizaçao Fluvial do Rio Sorraia. Simpdsio A Bacia Hidrográfica Portuguesa do Rio Tejo. Ediçoes da Associaçao Portuguesa de Recursos Hidricos. Lisboa.

FERREIRA, M.T., 1992. Estrutura e Dinamica das Comunidades de Macrófitos Ldticos da Bacia Hidrográfica do Sorraia. Doctoral Thesis. Instituto Superior de Agronomia. Lisboa. 410 p.

FERREIRA, M.T. \& J.C. FIGUEIREDO, 1990a. Bases de ordenamento lótico e sua aplicaçao ao rio Sorraia. Actas do II Congresso Florestal Nacional. Sociedade Portuguesa de Ciencias Florestais. Porto. pp.56-62

FERREIRA, M.T. \& J.C. FIGUEIREDO, 1990b. Conservation and management of Sorraia river, Central Portugal. International Conference on Conservation and Management of Rivers. Nature Conservancy Council. York.

FERREIRA, M.T. e I. MOREIRA, 1989. Impacte de actividades agricolas sobre a dinamica e evoluçao de macrófitos aquáticos no vale do Sorraia. Actas da II Conferencia Nacional sobre a Qualidade do Ambiente. Universidade de Aveiro. Aveiro. pp. 39-48

GARDINER, J.L. (ed.), 1991. River Projects and Conservation, a Manual for Holistic Approach. John Wiley \& Sons. Chichester.

HASLAM, S., 1978. River Plants. Cambridge University Press. Cambridge. 